Sohair Saeed A. Ahmed

\title{
Four Coptic Ostraca from Kharga Museum
}

In this paper are published and studied the only four Coptic ostraca kept in the Kharga Museum of the Kharga oasis under serial numbers 11231126. They are all potsherds and completely unpublished and found in a place called "El-hesn" ("the fortress") which lies about two kilometers north of "Ain Waqfa" at Ezbet "Maks Qibli" (south of El-kharga). The Photographs were taken by me in November 2008.

The preservation numbers, the dimension, the finder, the provenance and the general description of these ostraca are copied here from the registration file of the Museum but I added a description of both content (which was unknown) and script. Also I suggested the date and made paleographical tables of the letters.

\section{Hereunder marks used in both transcription and translation:}

[ ] Lacuna in the ostracon.

$[\triangle B \Sigma] \quad$ Lacuna with restored text.

$(\triangle B \Sigma)$ In transcription: letters erased entirely and suggested.

(abc) In translation: words not written in the Coptic text.

$<>\quad$ Letters omitted by the scribe.

$\{\triangle B \Sigma\} \quad$ Letters incorrectly written by the scribe.

... Letters which could not be read.

dị. $\quad$ Letters not clear entirely in the text.

$?$

Uncertain reading. 


\section{O. Kharga Mus.1}

Serial number: 1123.

Dimension: $14 \times 11.5 \mathrm{~cm}$.

Excavator's No.: 2266/3.

Thickness: $8 \mathrm{~mm}$.

Finder: The Egyptian Excavation of Elwadi Elgedeed archaeological site under supervision of Adel Hussen (1986).

Provenance: MAKS QIBLI-ELHESN, east of the fortress- the $2^{\text {nd }}$ level.

Description: A complete ostracon, brown pottery- ribbed in the outer part, 10 lines on verso with black ink.

Script: large, regular \& the letters are long.

Content: A private letter from "Yuhannes" to ask "Martais" to go to a woman in the north and search for a servant for her because she is sick. For this favor "Martais" will receive hire from the sender.

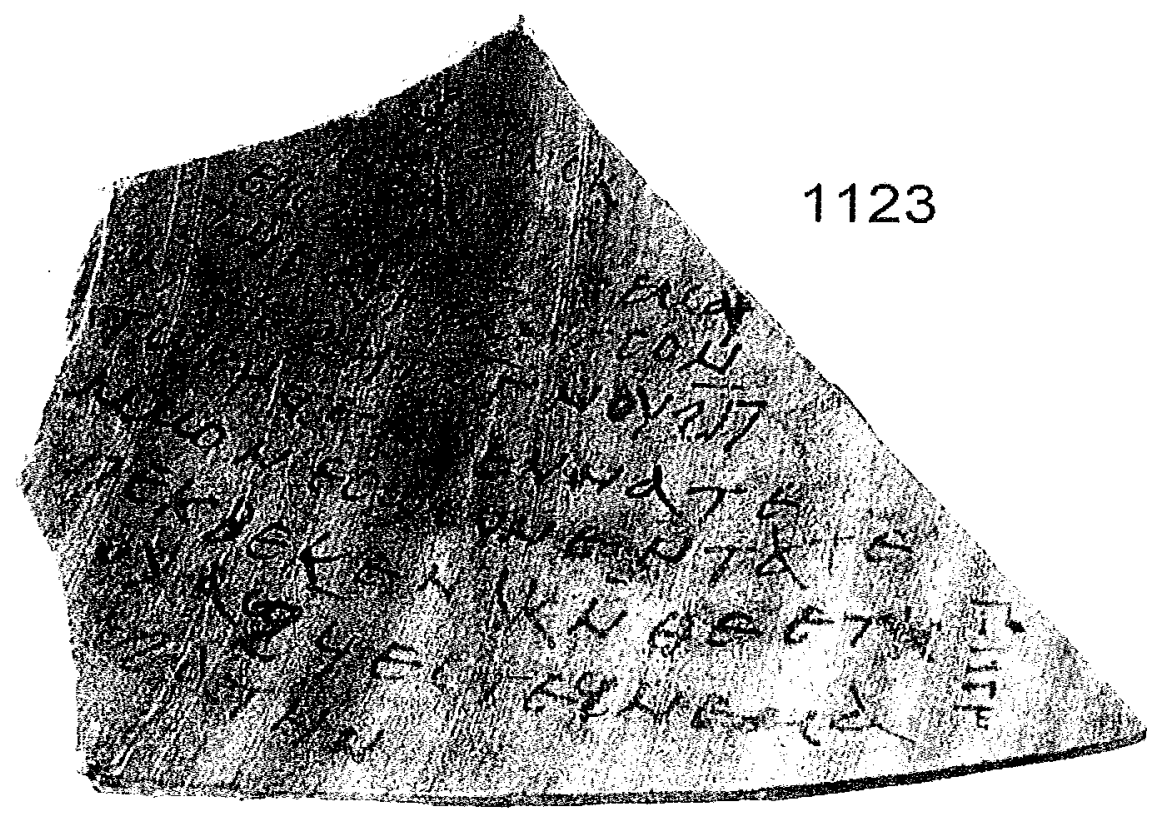




\section{Transcription}

Verso

1 - 卉 ANOK

2 - I02ANnH(C)

3 - elc2al elg(INe) emap-

4 - THC aPI TMNṬCON

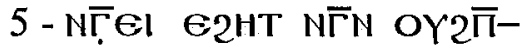

6 - TWPHTE NKENHATE

7 - MMON ECC)WNE NTdTE

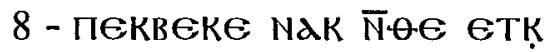

9 - oYdi) ECTEq NeMa[I]

10 - 2 dTHN

\section{Translation}

1 - $\mathrm{P}$

2 - "Yuhannes"

3 - I write greeting "Mar-

4 - tais", do brotherhood

5 - and come to north and bring a ser-

6 - vant for "Kenaite"

7 - for she is ill and I will pay

8 - your hire to you in the way which you

9 - desire (and) she (will) pay it with [me]

10 -

\section{Comment}

1.5-6: $2 \bar{\pi} \tau \omega \rho$ нте: It is probably the Greek word "servant" because "H. Förster" mentioned this word written in Coptic as $2^{\mu} \pi[$ [ЕРЕтн]c (Wörterbuch,s.834) and I think that it was written

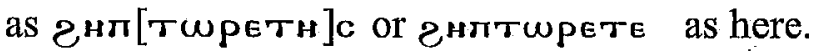

1.6: kerHate: It is probably a fem. proper name from the Greek word

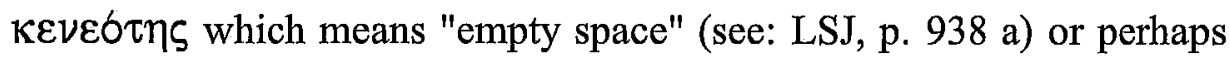


equal kers [ (in: Hasitzka, Namen,s.49), anyway it seems to be uncommon in Coptic.

1.7: «щor means "for or verily" before tenses \& imperative verbs (see: CD, p. 169 a). $T E=+$ inf. means "give, pay".

1.9: or a wy : the writer wrote 2 instead of $y$ as a mistake but he corrected it.

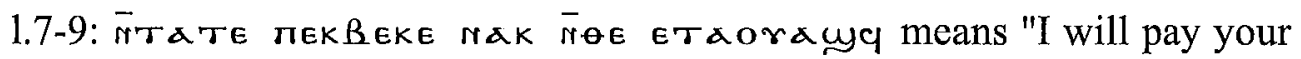
hire to you in the way which you like" namely he will give the hire to him personally or send it to him.

1.10 2a THr: There are more than one probability for the meaning of this word here as either var. of zrrores- "beside, next", ZaxEN"before" (of time) and a тxes - "without" (see: DI, 91, CD, 444b, $758 \mathrm{a}, 25 \mathrm{~b})$ or $2 \overline{\mathrm{a}}(2) \mathrm{THs}$; as compound preposition plus suffix pronoun means "with/ beside us" (Layton CG, p.169). 


\section{O. Kharga Mus.2}

Serial number: 1124.

Dimension: $18 \times 10 \mathrm{~cm}$.
Excavator's No.: $2281 / 8$.

Thickness: $1.3 \mathrm{~cm}$.

Finder: The Egyptian Excavation of Elwadi Elgedeed archaeological site under supervision of Adel Hussen (1986).

Provenance: MAKS QIBLI-ELHESN, the western chamber - the $3^{\text {rd }}$ level.

Description: An ostracon was divided into 4 parts then it was restored, pottery, a part of bowl - orange color - 6 lines on recto \& 8 lines on verso written with black ink.

Script: Regular, large and thick.

Content: A non-complete private letter sent from two persons called "Psumenais" and "Kanah" to a man seems to be a monk; his name is "Phibamon" and lived in "Tamoi". On verso where the text is starting, the senders inform the recipient that don't send the golden piece, called tremession, by someone (I read his name as "Ounoum") as they deal before because they don't confide in him and they ask to send by another person called "Thomas", also they mentioned that (on recto) they will give the tremession? to a man called "Praeiske" at south.

Verso

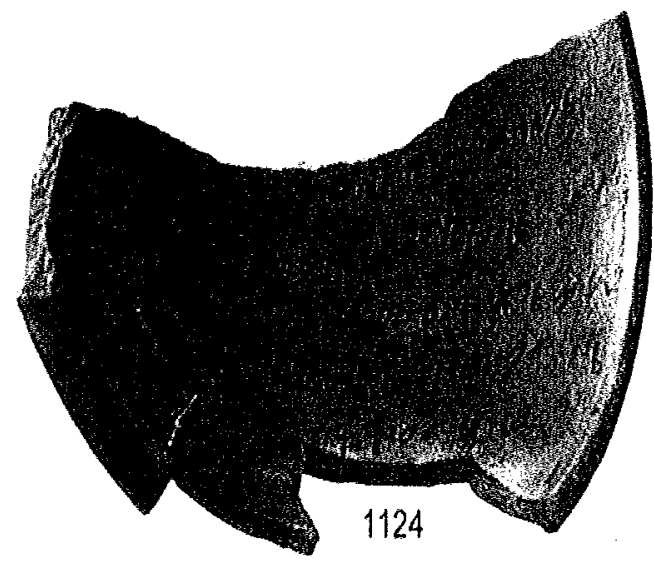




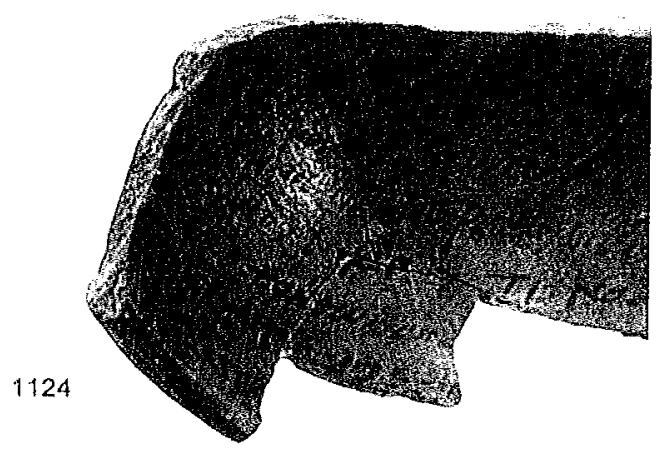

The bottom part of verso

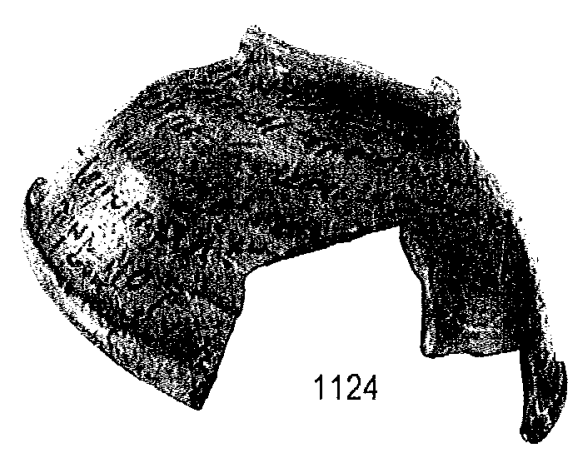

The lift side of recto

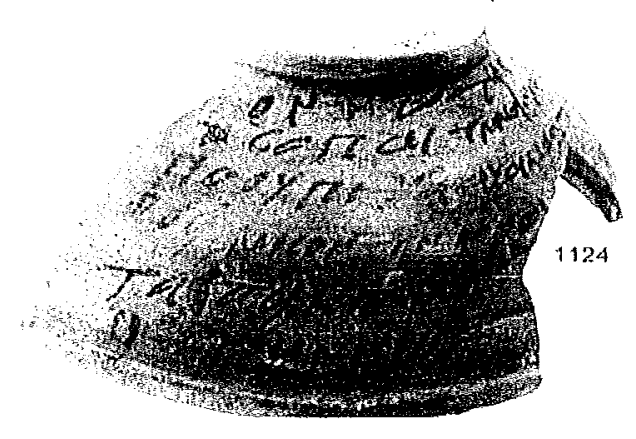

The middle part of recto 


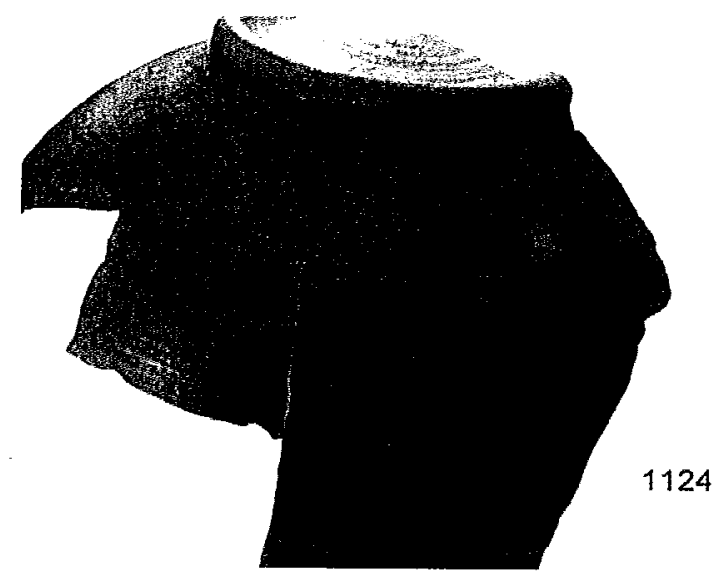

The right side of recto

\section{Transcription}

\section{Verso}

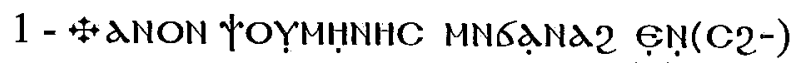

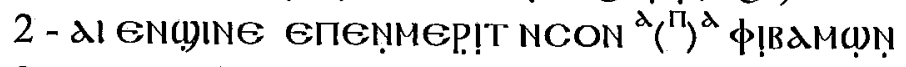

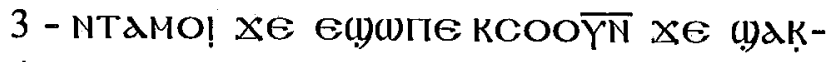

4 - TNNOOY ПTEPOMHCION NAN 2 ! TH

5 - OYNOYM Maq TNNOOYG Nan $2 l-$

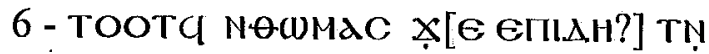

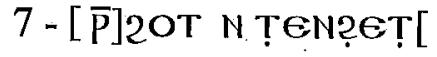

8 - мMо[м М̈ПтTNNOY птеромнСl-]

\section{Recto}

1 - ON MTOOTq $\in \mathrm{C}$ WOMT

2 - NCOI AITNNOY GMATENOY.[

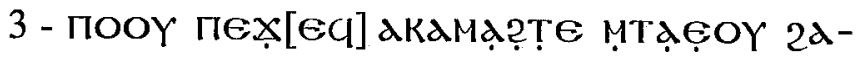

4 - POC MMON TNNOY [ПTEPOMHCION? N]TNEI EPHC TN-

5 - тадq ппрдае[іске

6 - .. TPM(H)CION [ ] EKฒגN TNNOY ]dK d! ? 


\section{Translation}

Verso:

1 - We "Psumainais" and "Kanah" we wri-

2 - te we greet our dear brother Apa "Phibamwn"

3 - of "Tamoi": if you know that you will

4 - send the tremession to us by

5 - "Ounoum" give it (and) send it to us

6 - by "Thomas" [ whereas ?] we

7 - fear to confide [in him?

8 - veril[y don't send the tremessi-]

\section{Recto:}

1 - on by his hand see! Three

2 - times I sent (and) agree upon them (with him)

3 - Today, it is him (that) sa[ys] (that) you seized the wage, for

4 - him verily send [the tremession?] and we will come south (and) we (will)

5 - give (or pay) it to "Prae[-iske" ] if you want to send $6-\ldots$ tremission $[\quad] \ldots . .$.

\section{Comment}

\section{Verso}

1.1: Foreussic is a proper name (masc.) and equal to $\psi \varepsilon \mu t v i s$ (in Greek) of an Egyptian origin means "the son of Min" (see: DN, p. 246) and I think that it was uncommon in Coptic.

1.2 वла: it was written above the line and $\pi$ is missing.

1.3 rareor seems to be the ancient name of the place of "El-hesn" but I ignore that if this region included "Ain Waqfa" in Antiquity or not especially this name is similar to terores which means "spring" (CD, p.198b), in Arabic "Ain" .There is a reference to a place name as ra $[\ldots]$ which may refer to raseor (see: Hall , p.122).

1.5: OYNOYM: I think that it was the Egyptian personal name wnmi (Ägy. PN, s.79 (16), this word means "right/ right side/ right hand" and known 
in Coptic as oYNam (Wb I ,s.322), "Crum" mentioned oYNOM as one of the Saihidic dialect forms of this word (CD, p. 483b) so oүNom> OYNOYM here (with addition of the letter $Y$ only). Until now in Egypt, there is the masculine personal name "Ayman" means "right" (as adjective of the masculine words) also the feminine personal name "Yumna" means "right" (as adjective of the feminine words).

\section{Recto}

1.1: $\epsilon \mathrm{c}=\operatorname{erc}(\mathrm{CD}, \mathrm{p} .85 \mathrm{a})$, it is equal the word "bos" which is said until now in Egypt to pay attention before the information (O. Cairo Mus., p. 18).

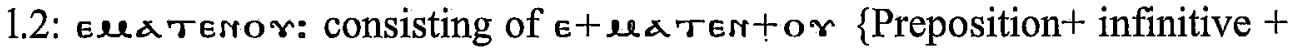
suffix pronoun (Plural)\}, this infinitive means "rest" or "agree upon" \& the Preposition $\mathrm{e}$ written usually when there is another infinitive written

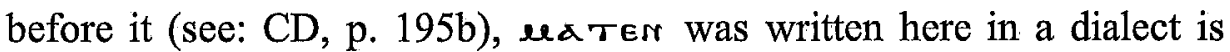

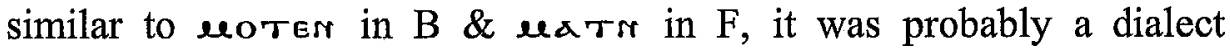
associated with the Kharga oasis in the case of the senders lived in this oasis.

1.3: Jaeor: I think that the writer means here the word $\operatorname{Tor}(\mathrm{E})$ ro which means also "wage" (see :CD, p.444b).

1.3-4 : 2Аpoq : Equal here two expressions are said by the Egyptians until now as "ashan khatroh" means "for his sake" or "ashan keda" means "for that" which are proceeded always by a reason, like this text.

1.5: $\mathrm{n}$ is not assimilated to $\mu$ before $\Pi$, лрделске: A proper name is mentioned in: PN, s. 102.

1.6: there are some letters (about 5 letters) written under the word тренскол, they are not clear and represent a word difficult to read. 


\section{O. Kharga Mus.3}

Serial number: 1125 .

Dimension: $13.3 \times 13.1 \mathrm{~cm}$.
Excavator's No.: 2282/19.

Thickness: $1.3 \mathrm{~cm}$.

Finder: The Egyptian Excavation of Elwadi Elgedeed archaeological site under supervision of Adel Hussen (1986).

Provenance: MAKS QIBLI-ELHESN, eastern north corner - the $3^{\text {rd }}$ level.

Description: An ostracon was divided into two parts then it was restored, pottery, light brown color, 11 lines with black ink.

Script: Regular, thin and large (except the letter o written very small also sometimes $p$ and $\mathbf{c}$ ).

Content: A list of men's names maybe of some villagers, 18 names still remaining, the names of the fathers are also given but some father's names are missing.

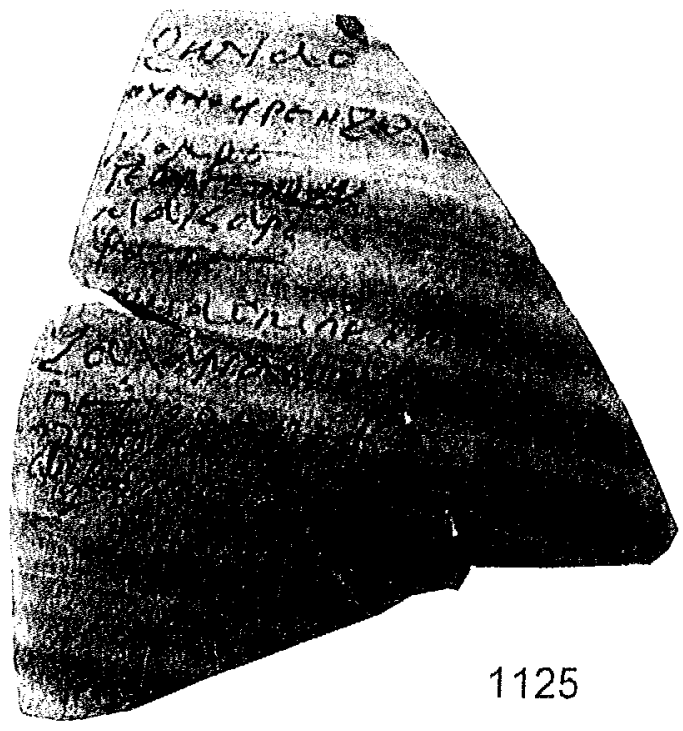




\section{Transcription}

\section{Recto}

$1-2 \mathrm{H} \lambda \mathrm{ALC}$

2 - OYONOCPE N2dג

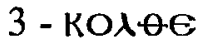

4 - гешрге N2OOY

5 - макаре

6 - үate

$7-1 \Theta]$. [н]мас мпєтрос

8 - ZdXXpld MldK/

9 - петрос мпєф[

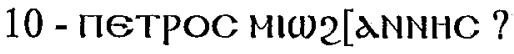

11 - фівAMWN <N> ZAKạp.[Ia

\section{Translation}

\section{Recto:}

1 - Helias

2 - Un-nefer (son) of Hal

3 - Colthe

4 - Gewrge (son) of Hoou

5 - Makare

6 - Psate

7 - E]r[e]mas (son) of Petros

8 - Zacharia (son) of Iakwb

9 - Petros (son) of Peph[ani?

10 - Petros (son) of Yuh[annes?

11 - Phibamwn (son) $<$ of $>$ Zachar [ia

\section{Comment}

The origin of the proper names is various between native Egyptian (pagan), Greek and Hebrew especially associated with Christianity. And the majority is known in the Thebaide Nome and Elephantine.

1.2: ororocpe "Unnefer", an epithet of "Osiris" (Hall, p. 110). 
1.7, 9: the letter $\mathrm{c}$ is written closed, similar to the o

1.8: "Iakwb" is written abbreviated.

1.11: the letter $\phi$ is written with an open circle. The writer omitted genitival $r$ because the name written before it ended with the letter $r$ and this matter was remarkable in the lists of names.

\section{O. Kharga Mus.4}

Serial number: 1126.

Dimension: $6.4 \times 5.4 \mathrm{~cm}$.

Excavator's No.: 2286/23.

Thickness: $1 \mathrm{~cm}$.

Finder: The Egyptian Excavation of Elwadi Elgedeed archacological site under supervision of Adel Hussen (1986).

Provenance: MAKS QIBLI -ELHESN, eastern north of the site.

Description: A part from an ostracon, pottery, reddish brown color, remains of 8 lines on both recto \& verso (the text is more destroyed on verso) written with black ink.

Script: Large, thick and regular.

Content: A small fragment difficult to determine its topic (maybe a part of a letter or a business text or perhaps a legal). The writers are more than one person.

Recto

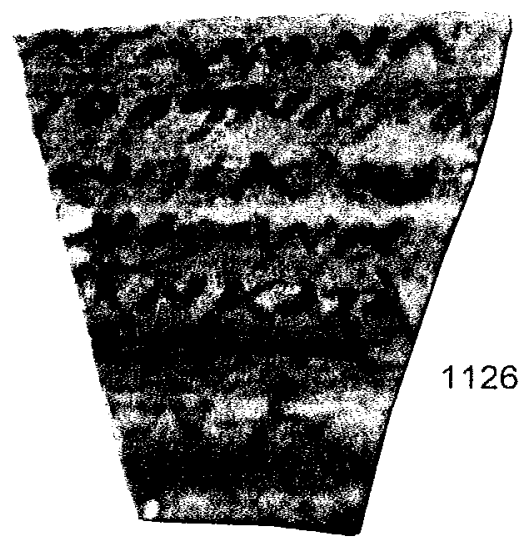




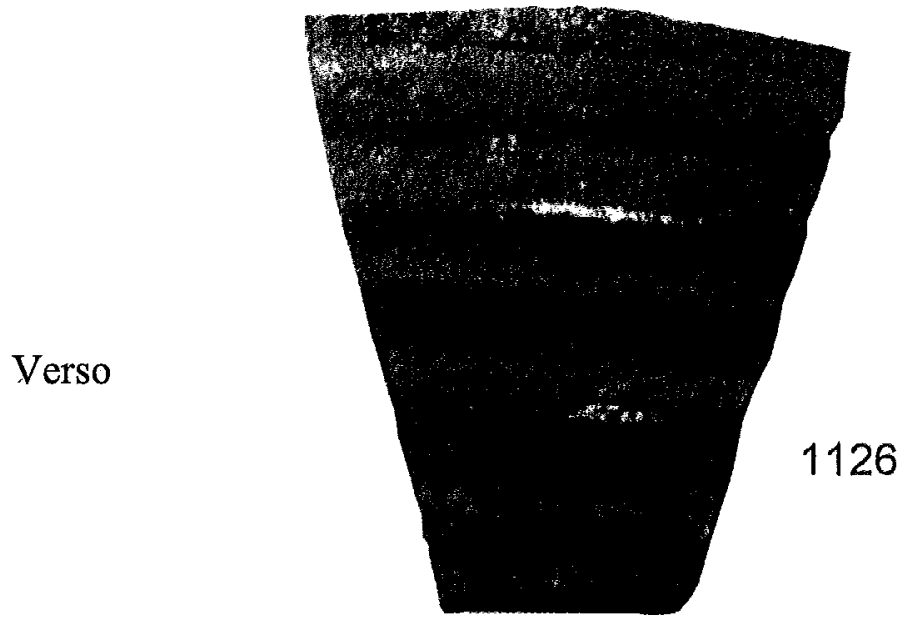

\section{Transcription}

\section{Recto}

1- o]pranon? N[

2 - ]TOOTN NNO.[

3 - ] $\omega$ пек' .[

$4-e]$ NC)AN N[

5 - ]в NKdTd [

6 - ]. TNTA[

7 - ]Ṭt[

8 - ]

\section{Verso}

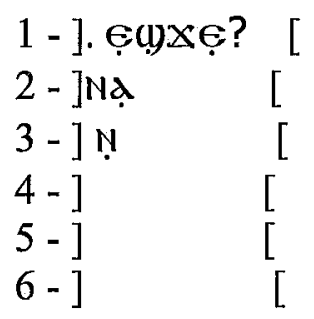


7 - ]N(y).

$8-] M$

\section{Translation}

\section{Recto}

1 - o]rganon? of

2 - ] the hand of us to... [

3 - ] your?[

4 - ] if we want to..[

$5-] \quad[$

6 - ] [

$7-][$

8 -] [

There is no suggested translation for verso.

\section{Comment}

\section{Recto}

1.1 I read the first word as OPГANON which is a Greek measure oprov or opravov as a dry measure also for cheese and wine (WS, p. 25), it is

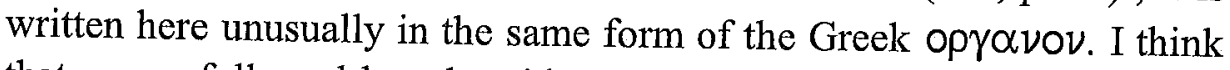
that $s$ was followed here by either a number or the measured object or an adjective like ro $\sigma$ to describe the measure (see: Wörterbuch, ss. 586-587).

1.2: тоотя may be егтоотr means "these are in the hand of us" as an expression of possession (O. Cairo Mus., p. 49) or uтоотs or 2 गооотr mean "by us".

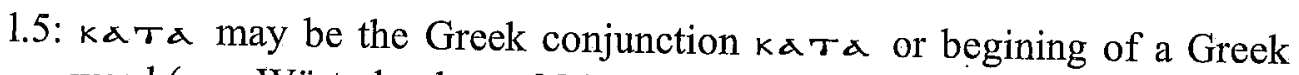
word (see: Wörterbuch, ss. 384-396).

\section{Verso}

1.1 It can be read as euyxe means "if". 


\section{The date}

It is unknown, but I estimate to be the Islamic period between the $7^{\text {th }}$ century and the beginning of the $9^{\text {th }}$ century $\mathrm{AD}$ according to the following matters:

\section{O. Kharga Mus. 1:}

* The preface formula (combined with the greeting) and the monogram $p$ were written in the Coptic letters between the $4^{\text {th }}$ and the $8^{\text {th }}$ century (see: Briefformular, s. 44 \& O. Cairo Mus., p. 15).

* The begging formula aps тusrocor which was known in the $7^{\text {th }} / 8^{\text {th }}$ century (Briefformular, ss. 34-35).

* The paleography can be dated from the $8^{\text {th }}$ century especially the 2 letter (Stegmann, ss. 12-13).

It means that this text may be ascribed to the $7^{\text {th }} / 8^{\text {th }} \mathrm{c}$. or the $8^{\text {th }}$ century.

\section{O. Kharga Mus. 2:}

* The "tremession" is written in the Coptic texts in similar forms to Tpouscror, written here, from the $7^{\text {th }}$ or the $7^{\text {th }} / 8^{\text {th }}$ or the $8^{\text {th }}$ century (see: Wörterbuch, ss. 820-822).

* The red - slip wares were extant in $695 \mathrm{AD}-$ the $9^{\text {th }}$ century (Rodziewicz, p. 74).

* The paleography of many letters such as $\alpha, E, \pi, 0, P, c, r, q$ can be ascribed to the $8^{\text {th }}$ century (see: Stegmann, ss. 11-13) also the impenetrable o can be dated from the $7^{\text {th }} / 8^{\text {th }}$ or the $8^{\text {th }}$ century (see: O. Cairo Mus., nos. 1,9 ) and the ligatures with $\in$ was so common in the $8^{\text {th }}$ century texts from Djeme (Green, p. 62). All these matters can ascribe the text to the $7^{\text {th }} / 8^{\text {th }}-9^{\text {th }}$ century. 


\section{O. Kharga Mus. 3:}

* Most of the names written in this list are mentioned in the collection that studied by "Hall" and he said that they were in vogue in the $7^{\text {th }}$ and the $8^{\text {th }}$ century (Hall, p.x).

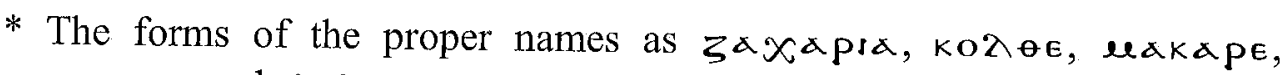
летрос and piвалеwr are mentioned in lists of names ascribed to the end of the $8^{\text {th }}$ century (see: Hall, pp.18-19).

* The paleography of some letters such as $\alpha, B, k, \lambda, \pi, r$ can be ascribed to the $8^{\text {th }}$ century (Stegmann, ss.11-13).

It means that this text can be ascribed to the $7^{\text {th }}-8^{\text {th }}$ century.

\section{O. Kharga Mus. 4:}

* The Greek measure opyov was used in the Coptic texts between the $6^{\text {th }} /$ $7^{\text {th }}-$ the $8^{\text {th }}$ century (Wörterbuch, ss.586-587)

* The raised apostrophe written after the letter $\mathrm{k}$ in the $3^{\text {rd }}$ line (on recto) which is written in the official Greek correspondence of the $7^{\text {th }}$ century (see: Green, p. 111).

So this text can be ascribed to the $7^{\text {th }}-8^{\text {th }}$ century. 


\section{Bibliography:}

- Ägy. PN=H. Ranke, Die Ägyptischen Personennamen I, 1935.

- $\mathrm{B}=$ Bohairic.

- Briefformular $=$ A. Biedenkopf - Ziehner, Untersuchungen zum Koptischen Briefformular unter Berücksichtigung Agyptischer und Griechischer Parallelen, Würzburg 1983.

$-\mathrm{BSAC}=$ Bulletin de L'Société D'Archéologie Copte, Le Caire 1935ff.

- CD = W.E. Crum, A Coptic Dictionary, Oxford 1939.

- DI= M. Strasbach, B. Barc, Dictionnaire Inversé du Copte, Louvain 1982.

- DN= E. Lüddeckens, Demotishes Namenbuch 12, Wiesbaden 2000.

$-\mathrm{F}=$ Fayyumic.

- LSJ= H.G. Liddell \& R. Scott, Greek English Lexicon, Oxford 1986.

- Green=M. Green, "A private archive of Coptic letters and documents from Teshlot" OMRO 64 (1983).

- Hall = H. R. Hall, Coptic and Greek Texts of the Christian Period from Ostraka, Stelae, etc. in the British Museum, Oxford 1905.

- Hasitzka, Namen = M. Hasitzka, Namen in Koptischen Dokumentarischen Texten , 2006.

- Layton C.G. = B. Layton, A Coptic Grammar, Wiesbaden 2000.

- O. Cairo Mus. = S. S. Ahmed, A group of Unpublished Coptic Ostraca in the Cairo Museum I, $2^{\text {nd }}$ ed., Cairo 2008.

- OMRO = Oudheidkundige Mededelingen uit het Rijksmuseum van Oudheden te Leiden .

- PN =G. Heuser, Die Personennamen der Kopten I , Leipzig 1929.

- Rodziewicz $=$ M. Rodziewicz, "Egyptian Glazed pottery of the eighth to ninth centuries", BSAC XXV (1983).

- Stegmann = D. Stegmann , Koptische Paläographie ,Heidelberg 1936. 
- Wb I = A. Erman und H. Grapow, Wörterbuch der Aegyptischen sprache, B.I, Leipzig 1926.

- Wörterbuch $=$ H. Förster, Wörterbuch der Griechischen Wörter in den Koptischen Dokumentarischen Texten , Berlin 2002.

- WS = W.E. Crum and H.I. Bell, Wadi Sarga Coptic and Greek Texts, 
Four Coptic Ostraca from Kharga Museum

The paleographical tables (the $7^{\text {th }}-9^{\text {th }}$ century $A D$ ):

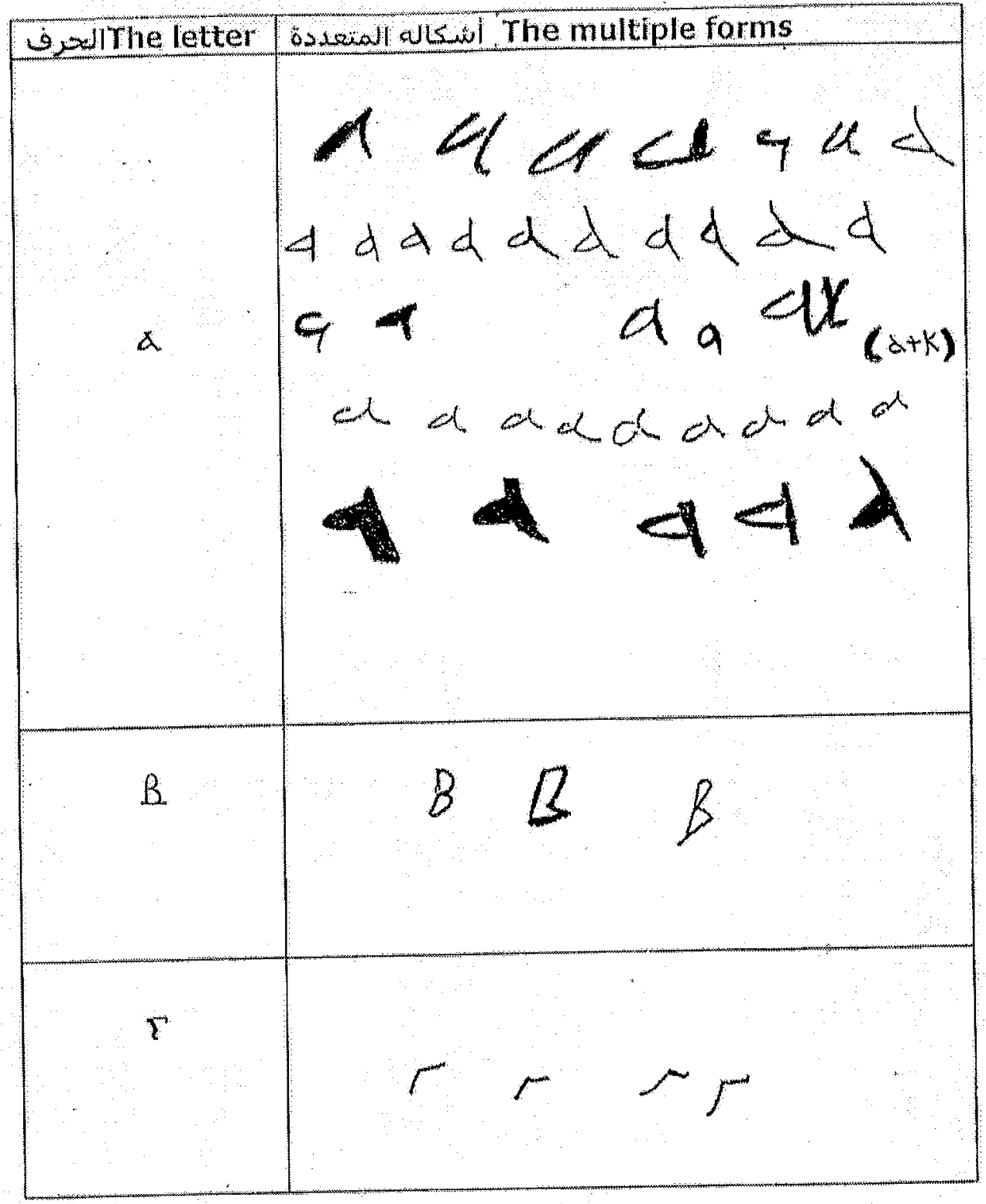

181 


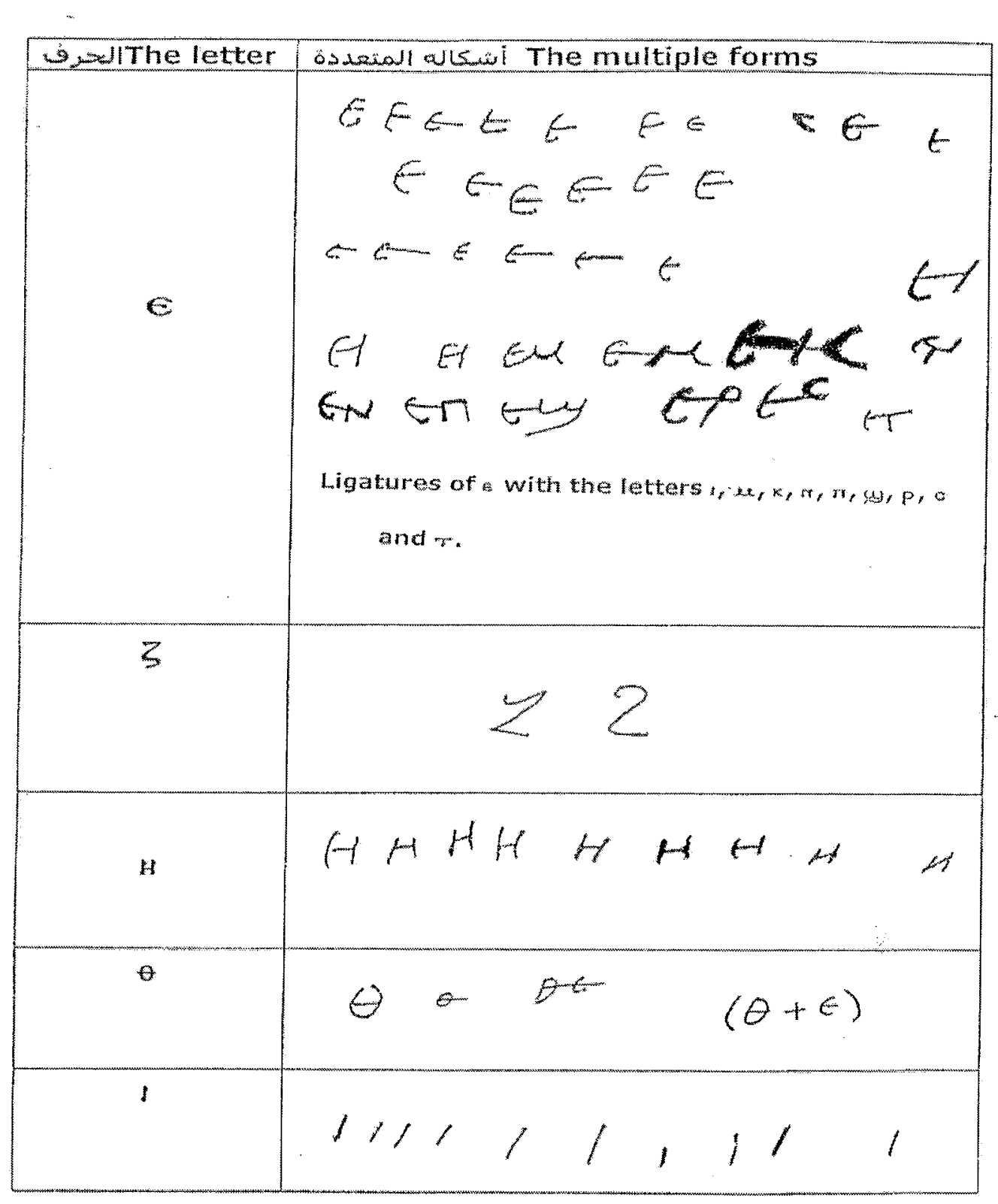




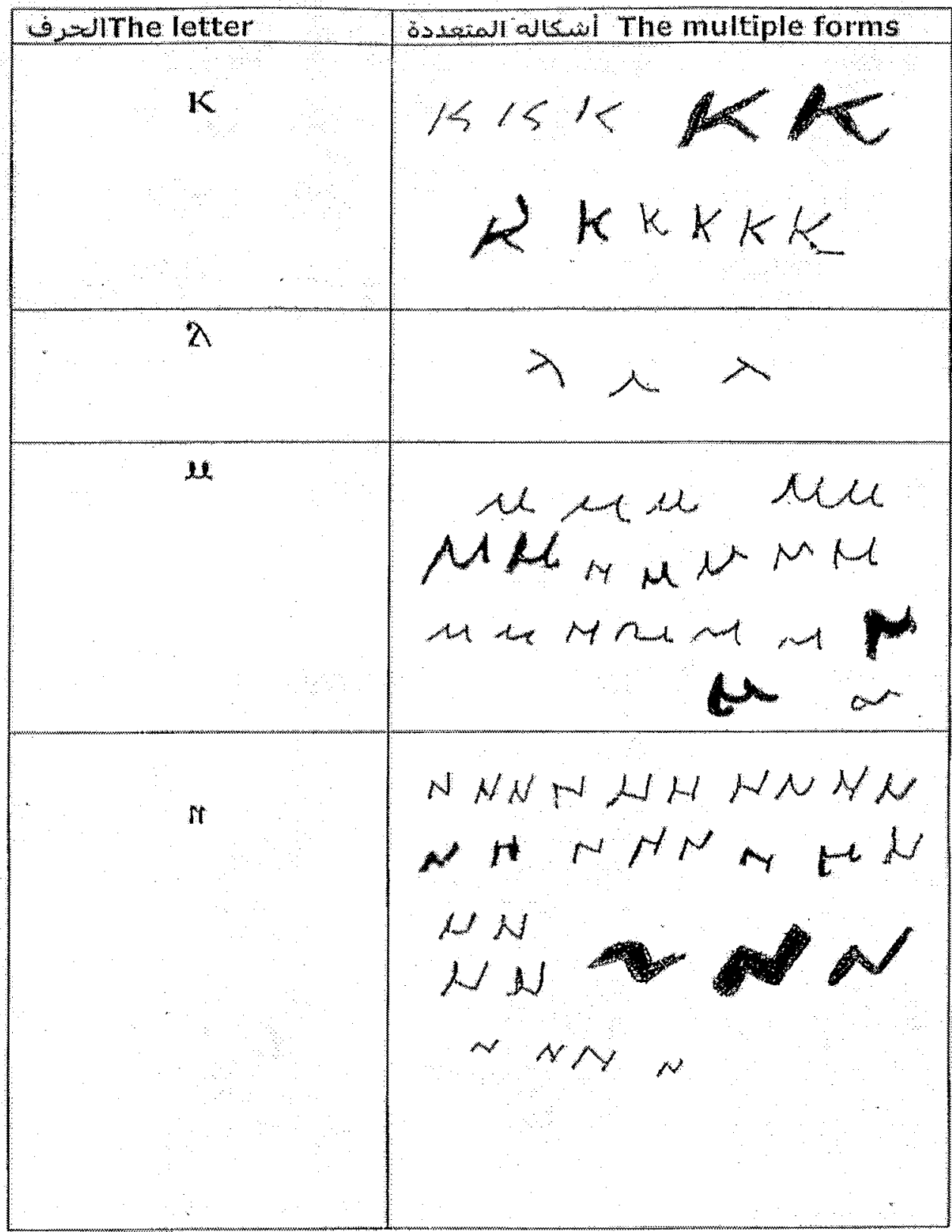


Four Coptic Ostraca from Kharga Museum

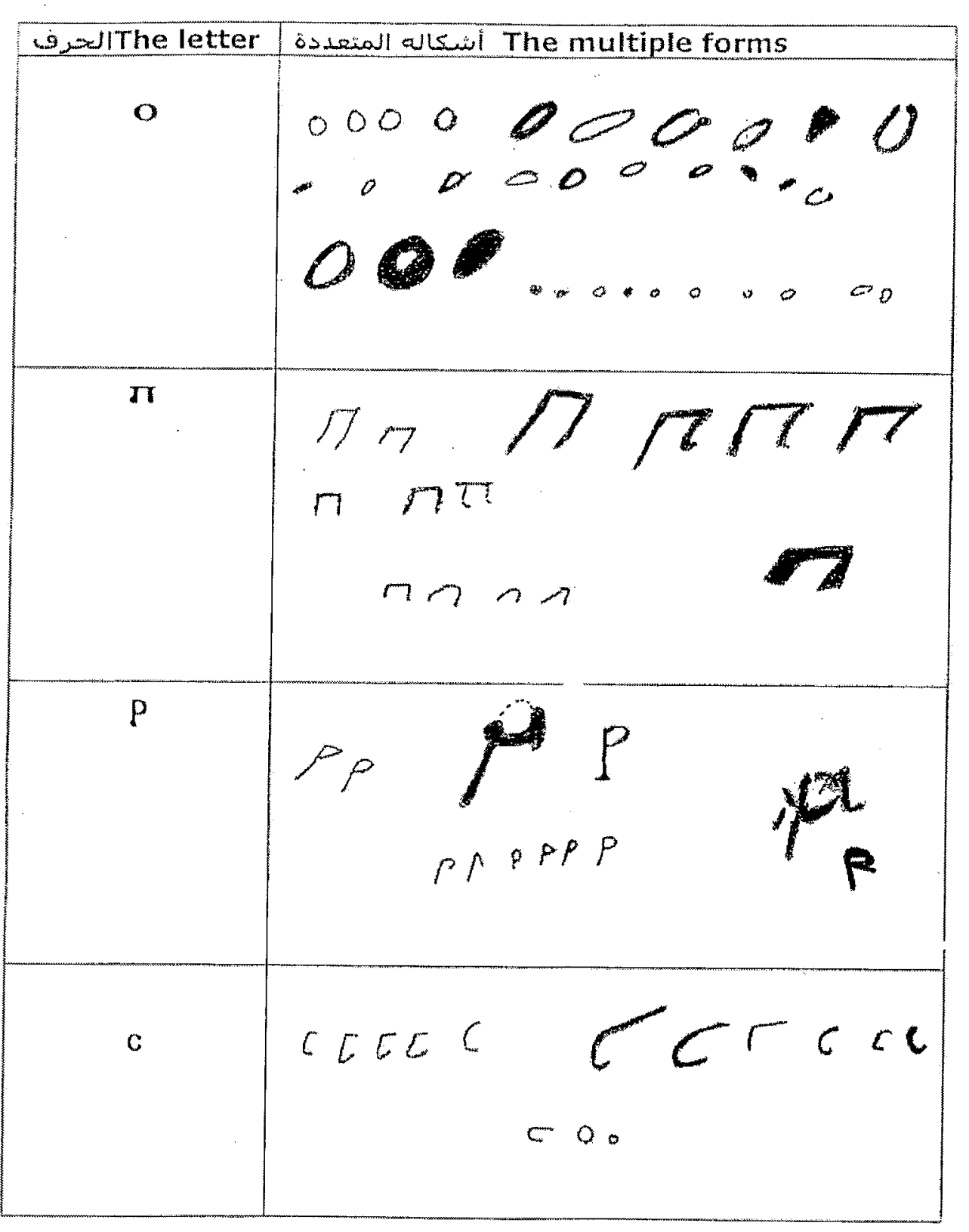

184 


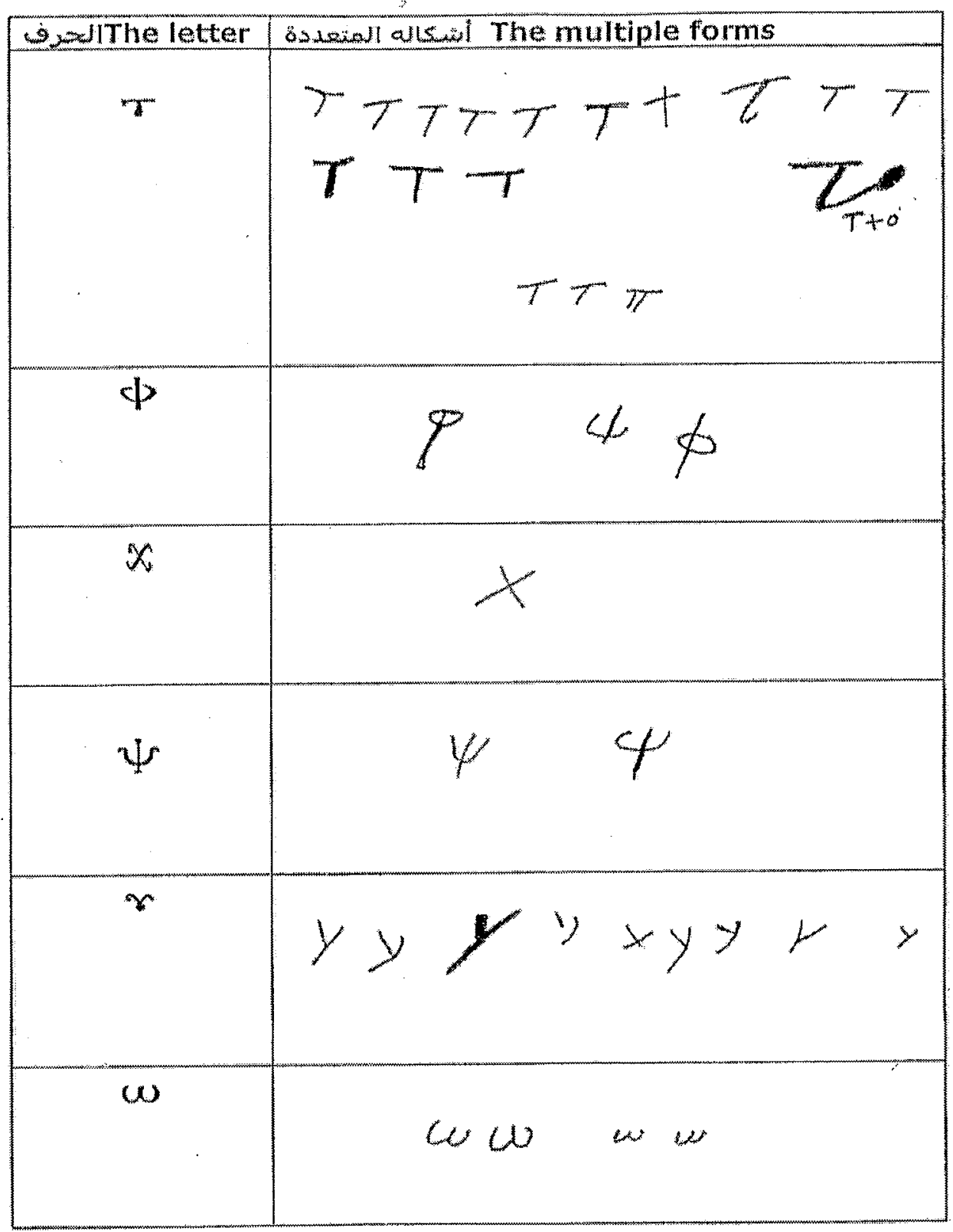


Four Coptic Ostraca from Kharga Museum

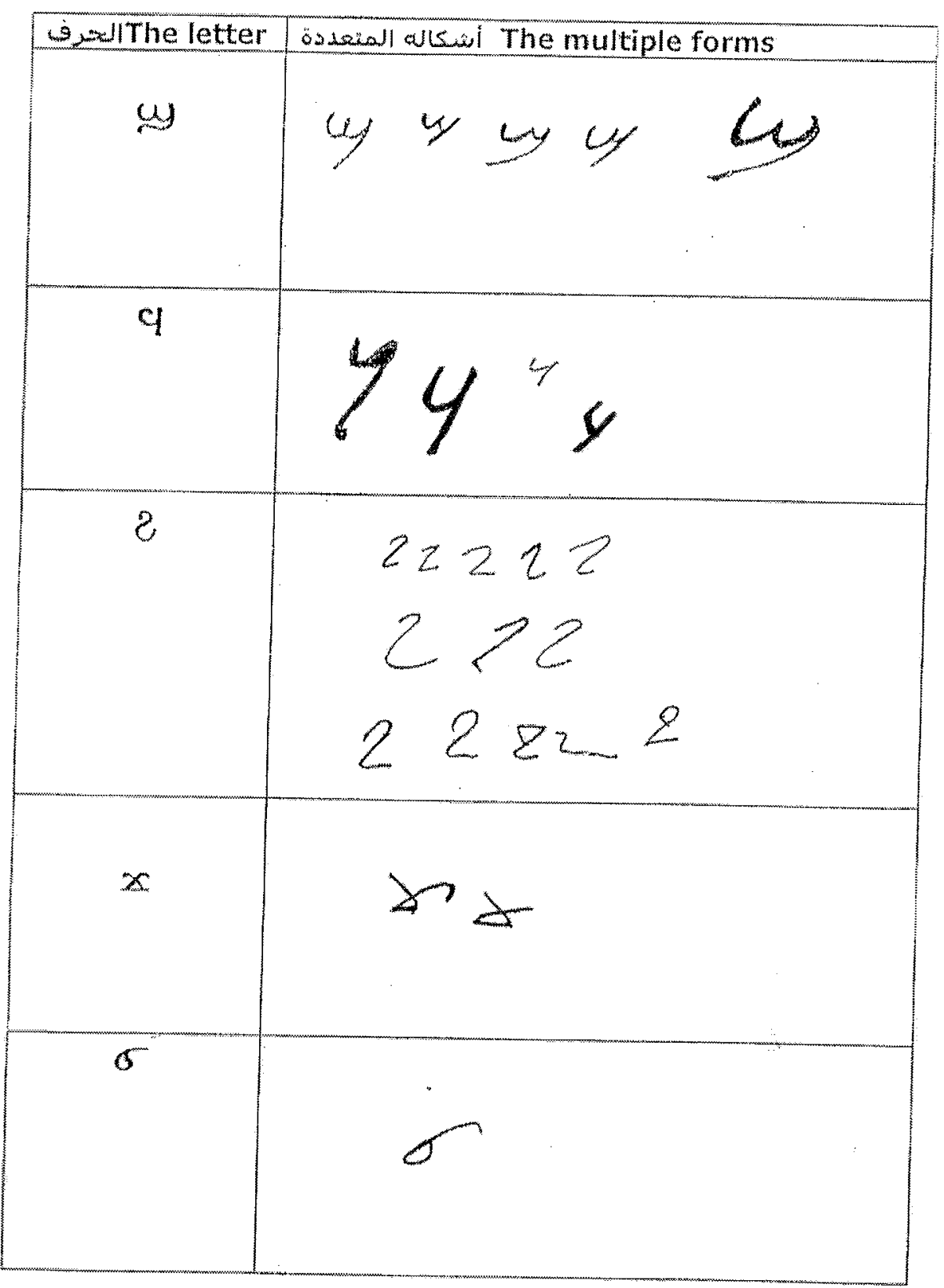

186 